Jurnal Bisnis dan Manajemen, Volume 20, No. 1, March 2019, p. 71-88

\title{
IMPROVING EMPLOYEE PERFORMANCE THROUGH ORGANIZATIONAL CULTURE, LEADERSHIP, AND WORK MOTIVATION: SURVEY ON BANKING ORGANIZATIONS IN SOUTHEAST SULAWESI
}

\author{
Wa Ode Zusnita Muizu ${ }^{1}$, Diana Sari ${ }^{2}$ \\ 1,2 Universitas Padjadjaran, Indonesia
}

\begin{abstract}
This research aims to identify the effect of organization culture, leadership, and work motivation on employee performance of banking organizations in Southeast Sulawesi. The methods used in this research are a descriptive survey and explanatory survey. Hypotheses testing was conducted using the Structural Equation Model (SEM). Meanwhile, data processing was done using Lisrel 8.72 program. The first hypotheses test result showed that organizational culture has a significant and positive effect on leadership. The second hypotheses test result showed that organizational culture has a significant and positive effect on employee work motivation. The third hypotheses test result showed that organizational culture and leadership have significant effects, both partially and simultaneously, on work motivation. The fourth hypotheses test result showed that organizational culture, leadership, and work motivation have a significant effect, both partially and simultaneously, on employee performance.
\end{abstract}

Keywords: employee performance, leadership, work motivation, organizational culture

\section{MENINGKATKAN KINERJA KARYAWAN MELALUI BUDAYA ORGANISASI, KEPEMIMPINAN, DAN MOTIVASI KERJA: SURVEY PADA PERBANKAN DI SULAWESI TENGGARA}

\begin{abstract}
ABSTRAK
Penelitian ini bertujuan untuk mengetahui pengaruh budaya organisasi, kepemimpinan, dan motivasi kerja, terhadap kinerja karyawan perbankan di Sulawesi Tenggara. Metode penelitian yang digunakan adalah descriptive survey dan explanatory survey. Alat uji hipotesis yang digunakan adalah Structural Equation Model (SEM), sedangkan untuk pengolahan data menggunakan program Lisrel 8.72 (Linier Structural Relationship). Hasil pengujian hipotesis pertama menunjukkan bahwa budaya organisasi berpengaruh secara signifikan dan positif terhadap kepemimpinan. Hasil pengujian hipotesis kedua menunjukan bahwa budaya organisasi berpengaruh secara signifikan dan positif terhadap motivasi kerja karyawan. Hasil pengujian hipotesis ketiga menunjukan bahwa budaya organisasi dan kepemimpinan berpengaruh secara signifikan baik parsial maupun simultan terhadap motivasi kerja. Hasil pengujian hipotesis keempat menunjukan bahwa budaya organisasi, kepemimpinan, dan motivasi kerja, berpengaruh secara signifikan, baik parsial maupun simultan terhadap kinerja karyawan.
\end{abstract}

Kata-kata Kunci: budaya organisasi, kepemimpinan, kinerja karyawan, motivasi kerja

Korespondensi: Dr. Wa Ode Zusnita Muizu, S.E., M.Si. Fakultas Ekonomi dan Bisnis Universitas Padjadjaran. Jln. Dipati Ukur No. 35 Bandung, Jawa Barat 40132. Email: waode.zusnita@unpad.ac.id 
Jurnal Bisnis dan Manajemen, Volume 20, No. 1, March 2019, p. 71-88

\section{INTRODUCTION}

Banking industry is the generator of the Indonesian economy, acting as one of the development agents. The banking industry has a positive image in the eye of customers since the customers still trust the banks to manage their fund. The number of customers keeps growing, but some of them also complain about the lacking services they get. This situation primarily happens in regional banks.

Based on the pre-survey result conducted in South East Sulawesi banks, it is indicated that the efforts to anticipate the effect of the global economy are not optimal yet. It is seen from the facts that i) some employees conduct the activities which do not have any relationship with their job, ii) the punctuality of the employees is terrible resulting in non-optimal services, iii) many complaints from customers about the lack of responsiveness of bank staff, iv) there are employees who are reluctant to ask their boss if they face problems, and v) there are still misconducts such as giving loan to those who may not be able to repay it. These situations may happen in other banks outside Southeast Sulawesi.

Banks in South Sulawesi need to improve their competitiveness and rebuild customer trust by increasing the role of human resources in achieving their vision and missions. One of the ways to do that is by increasing the professionalism of human resources which is oriented to the needs and wants of customers and supported by the improvement in structure, strategic management, and organizational culture which is appropriate, creative, flexible, innovative, and adaptive. Also, these efforts should also be supported by implementing effective leadership and highly-motivating environment so the performance of employees may increase.

Based on the explanation above, first, this research is aimed at describing organizational culture, leadership, motivation, and employee performance. Second, this research aims to identify the effect of organizational culture on leadership. Third, this research aims to identify the effect of organizational culture on motivation. Fourth, this research aims to explore the effect of organizational culture and leadership on motivation, both partially and simultaneously. Moreover, the last, this research aims to explore the effect of organizational culture, leadership and motivation on employee performance, both partially and simultaneously in banks in Southeast Sulawesi.

\section{LITERATURE REVIEW}

\section{Organizational culture}

Organizational culture is defined as a system of values that is believed by all members of the organization and studied, applied and developed continuously. Hofstede (2005) explained that values are formed early in a person's life through the environment where he grows. Measurement of organizational culture is often associated with what dimensions which can be used to measure organizational culture. 
Jurnal Bisnis dan Manajemen, Volume 20, No. 1, March 2019, p. 71-88

Hofstede et al. (1991) suggested several dimensions of the measurement of organizational culture. The first dimension is process-oriented versus result-oriented which describes the courage to face risk, tolerance for mistakes, and comfort in unfamiliar situations. The second is employeeoriented versus job-oriented which describes the making of important decisions, pressure in completing work, and concern for employee welfare. The third is parochial versus professional related to employee education and employee views on the organization, as well as the company's basis in choosing employees. The fourth is an open system versus a closed system that is related to the attitude of the organization to outsiders, attention to the physical environment of the workplace, and acceptance of new ideas in the company. The fifth is loose control versus tight control such as awareness of the work environment on costs arising from organizational activities, the time of meetings conducted, and supervision of work. The sixth is normative versus pragmatic which describes the company's contribution to society, concern for results or procedures, and emphasis on meeting customer needs.

The measurement model of organizational culture as proposed by Hofstede (1991) is a flexible model that can be applied in various organizations. This measurement model is purely derived based on the results of crossorganizational research that refers to the core of culture. Hofstede's six main dimensions produced through cross-organizational research, if 
Jurnal Bisnis dan Manajemen, Volume 20, No. 1, March 2019, p. 71-88

\section{Work motivation}

Motivation is essential to achieve optimal performance. Work motivation is defined as the tendency of traits found in a person arousing encouragement and directs his behavior towards achieving the organizational goals.

From various motivational theories, employee motivation can be classified into three dimensions (Osteraker, 1999). The first dimension is the social dimension that is closely related to communication within the organization, employee solidarity in the organization, and openness in interaction. The second dimension is the mental dimension that is closely related to the discipline applied in the organization, interest in work, and promotion of career paths. Moreover, the third dimension is the physical dimension which is related to compensation, security in work, and respect for the work done.

\section{Employee performance}

Performance is used by management to conduct periodic assessments of the operational effectiveness of the organization and employees based on the predetermined standards, targets and criteria.

Regarding the dimensions of employee performance assessment, there is a Personal Balanced Scorecard model that is part of the Total Performance Scorecard. Personal Balanced Scorecard model is a breakthrough in measuring employee performance. This model can balance the personal ambitions of employees and goals to be achieved by the organization where those employees work. According to the concept of Total Performance Scorecard, task development, individual and organizational capabilities are the main focuses.

Assessment of employee performance in the innovative and adaptive organizations is related to financial perspective relating to the received income and financial management. Internal perspectives are related to comfort and discipline in work and satisfaction in enjoying pleasant things in life. External perspectives are related to the ability to work together, leader's trust, and perceptions about group performance and personal relationships. Knowledge and learning perspectives are related to the opportunities for self-development, quality of work, and improvement in employee work in the organization.

Based on various studies conducted by previous researchers focusing on organizational theory, organizational behavior, and human resource management, this study found that there is relatively no research investigating the influence of organizational culture, leadership, and work motivation on employee performance integrated using the Personal Balanced Scorecard. Personal Balanced Scorecard is a part of Total Performance Scorecard concept and also a performance appraisal concept that improves the Balanced Scorecard method developed by Kaplan.

Currently, dynamic knowledge-based organization to achieve success, his presence depends on the creativity and innovation that are 
performed by the employees. To ensure this can happen, the organization through its leaders tried to create a framework of institutional where creativity and innovation are used as the basic cultural norms in the midst of technological change and more. To deal with this, the culture of the Organization holds a very important role, especially in stimulating the birth of creativity and innovation in organizations (Martins \& Terblanche, 2003).

Organizational culture is manifested as organizational characteristics is a value system that is believed by all members of the organization and which is studied, applied and developed continuously, which can function as an adhesive, and can be used as a benchmark for behaving within an organization to achieve predetermined goals through a Process-oriented dimension versus result-oriented, Employee-oriented versus joboriented, Parochial versus professional, Open system versus closed system, Loose control versus tight control, and Normative versus pragmatic.

The need for an adaptive, flexible and innovative organizational culture in organizations in response to turbulence and uncertainty in the organizational environment is highly desirable. For this reason, leadership roles cannot be separated. One way to explain the relationship between organizational culture and leadership is to explain how organizational culture is conceptualized in organizational theory. Interwoven between organizational culture and leadership, can be seen from the context of the organization's life cycle (Schein, 1992) which 
related to compensation, security in work, and respect for the work done.

Development Organizational culture, leadership, and motivation together also affect employee performance. The relationship between leadership, motivation, and organizational culture on performance. Performance of tasks in the organization is determined / influenced by development strategies in: (i) individuals, which include motivation (ii) tasks, which include goals, and targets; (iii) the team, which includes leadership, norms and values, and match, and (iv) organization, which includes structure, climate, development support, and culture (Kopelman, 1986; Shamir, 1991; and Martins and Terblance, 2003). In addition, indirectly, organizational culture influences employee performance which is mediated by leadership and work motivation. This can be understood, that organizational culture provides a strong foundation in the selection of leadership models and supports the implementation of improved performance through a need approach related to work motivation for culture that supports work teams, owners and companies and is focused on achieving employee performance continuously. (Petty et. al, 1995; Franco \& Bourne, 2003; Nudurupati, 2003).

Finally, this study examines the causal relationship of organizational culture, leadership, and work motivation on the performance of banking employees using the Total Performance Scorecard method (Rampersad, 2003) which in the previous studies, this model has never been used.
Based on theoretical and previous studies, the paradigm in this study can be visualized in the following figure:

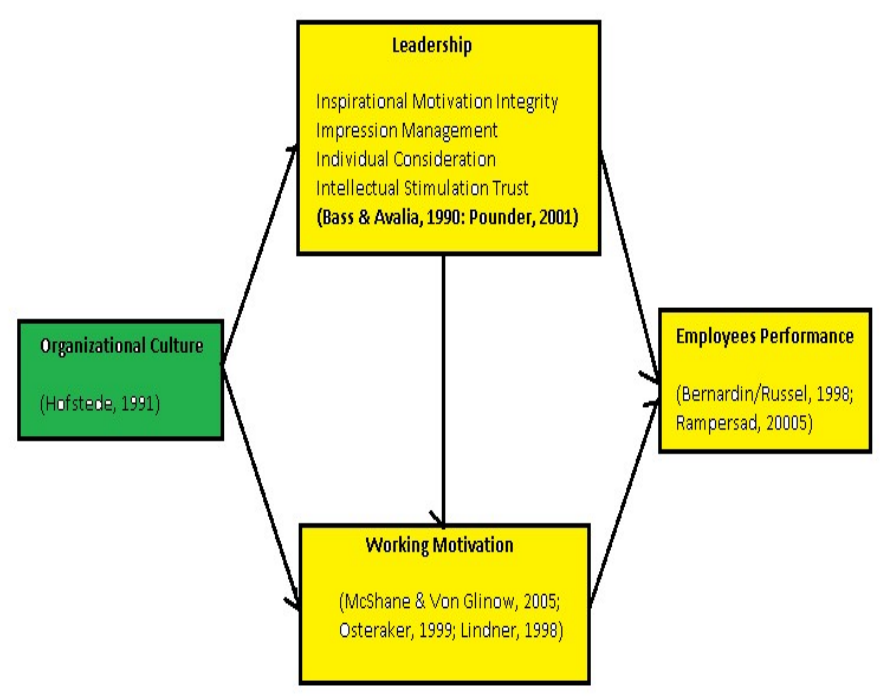

Figure 1. Research paradigm

\section{Hypothesis}

Based on the framework and premise that has been described, the research hypothesis can be proposed as follows :

Hypothesis 1: Organizational culture affects leadership

Hypothesis 2 : Organizational culture affects work motivation

Hypothesis 3 : Organizational culture and leadership affect work motivation

Hypothesis 4 : Organizational culture, leadership, and motivation affect employee performance

\section{METHODS}

This study uses the approach of human resource management and organizational behavior concerning organizational culture, leadership, work motivation, and employee performance 
variables. From its nature, this research is descriptive and verificative research.

The population in this study were 560 employees consisting of 81 leaders and 479 employees. Because the focus of this study is employee performance, the data to be processed is related to the data from employees totaling 479 employees. All employees are used as research samples. The respondents in this study will be given a number of questionnaires that will be filled based on the variables studied. The questionnaire distribution process is carried out through the division heads of each of the banking units studied. Respondents then filled out questionnaires whose results would be collected through the head of the unit to be processed and analyzed.

The analytical tool used is the Structural Equation Model (SEM). The data in this study were obtained using library research and field research through interviews with respondents, field observations, and questionnaire dissemination. The questionnaires were given to banking respondents in Southeast Sulawesi who did not hold leadership positions. The results of the questionnaires were then transformed using the transformation method, namely the method of successive intervals (Hays, 1976). In general, the answers of respondents were measured using a Likert scale with the values of 1, 2, 3, 4 and 5. Each obtained score is an ordinal measurement.
RESULTS AND DISCUSSION

\section{Organizational culture}

The average score of the culture of the Southeast Sulawesi banking organizations is 1887.11 . This average score is included in the category of high. It indicates that the Southeast Sulawesi banking organizations have a standardized organizational culture model set by each head office to be applied by each branch and branch office. Organizational culture tends to be well patterned and makes it easier for employees to carry out various jobs given to them because all types of work are standardized according to their respective workloads. With a standard organizational culture pattern, employees are expected to be able to improve their performance. In measuring the cultural dimensions of Southeast Sulawesi banking organizations, the highest average score is indicated by the dimensions of open systems vs. closed systems $($ score $=1909.67)$. It illustrates that the openness system that is applied, primarily related to openness in accepting ideas in the framework of improvement in the organization and openness in accepting new employees as part of the company has also been appropriately implemented. The lowest average is indicated by the dimensions of employee orientation vs. task orientation $($ score $=1874.00)$ which indicates that this orientation pattern has not been fully implemented properly.

\section{Leadership}

Based on respondents' responses, the average leadership score is 1868.81 . This score includes in 
Jurnal Bisnis dan Manajemen, Volume 20, No. 1, March 2019, p. 71-88

the category of good. Thus, the leadership applied in the Southeast Sulawesi banking organizations is excellent in giving positive contributions to the employees so they can achieve better performance. This condition also implies that leadership is quite motivating in improving employee performance as desired by the organization. The leaders of the banking organizations have the ability to inspire their employees through a good example, have high integrity, create innovations supporting high performance, have proper impression management, have individual considerations that are in the interests of employees, have a right level of intellectual stimulation, and have reliable honesty.

Based on the seven dimensions of leadership, the highest average score obtained from the dimension of leadership is inspirational motivation with a value of 1918.33. This score includes in the category of good. It shows that inspirational motivation applied in banking organizations is the most prominent thing that is applied to employees of banking organizations and can be used as the main driver in motivating employees in banking organizations while the lowest average score of the leadership dimension is the innovation dimension $($ score $=1831.50)$.

\section{Work motivation}

The average score of employee motivation in Southeast Sulawesi banking organizations is 1817.67. This score includes in the good category. It shows that dynamic organizations, the banks can understand the things that can spur employees to be motivated at work for creating better performance.

The dimension with the highest score on employee work motivation is the mental dimension with an average score of 1838 (good category). It means that employees in Southeast Sulawesi banking organizations are well motivated through the mental dimension imposed by the companies where they work. While the lowest average score is the social dimension with the score of 1797.33. It indicates that, generally, social relations in banking generally tend to be well established but have not been able to motivate the employees.

\section{Employee performance}

The average performance score of Southeast Sulawesi banking employees is 1856.33. This score includes in the good category. It indicates that in general, Southeast Sulawesi banking employees tend to have good performance through organizational culture, leadership applied in the company, and work motivation.

Furthermore, among the dimensions of employee performance, the highest average is shown by the dimension of the employee financial perspective (score $=1893.00$ ). This score shows that the achievement of employee performance, measured by the economic dimensions of employees, tends to be good, although there are also conditions where other employees do not have proper achievement. The lowest average score is 
Jurnal Bisnis dan Manajemen, Volume 20, No. 1, March 2019, p. 71-88

indicated by the dimension of knowledge perspective and employee learning (score = 1838.00). This score shows that in general the knowledge process and employee learning were not achieved well compared to other dimensions. This situation, of course, can prevent employees from innovating and creating ideas that motivate them to achieve the goals of the companies.

\section{Effect of organizational culture on leadership}

Table 1 shows that in the Southeast Sulawesi banking organizations, there was an influence of organizational culture on leadership by 0.55 . This result is in line with Bass (1990), Hofstede (1991), Blanchard and Wakin (1991), Schein (1992), Yousef (1998), Ogbonna and Harris (2000), Yukl (2001) stating that organizational culture, especially the constructive organizational culture, influences leadership in facing various changes and uncertainties in the organizations.

Table 1. Decomposition of the effect of the exogenous latent variable on the endogenous latent variable (leadership)

\begin{tabular}{cccc}
\hline Exogenous & \multicolumn{2}{c}{ Effect } & Total \\
\cline { 2 - 4 } latent variable & Direct & Indirect \\
Culture & 0.55 & - & 0.55 \\
\hline
\end{tabular}

Organizational culture provides a strong basis for the selection and application of an appropriate leadership model in the organization. Organizational culture can also be used as a determinant of a leadership model through the characteristic of the task provided in the organization which is the part of the culture itself. Furthermore, through the interaction of several complex factors within the organization, a leader can implement the appropriate decision-making style. Another important thing is the organizational culture because it can affect the effectiveness of leadership application in the organization. Besides, organizational culture also provides the basis for an organization management system. Moreover, organizational culture can be considered as a function of leadership and management.

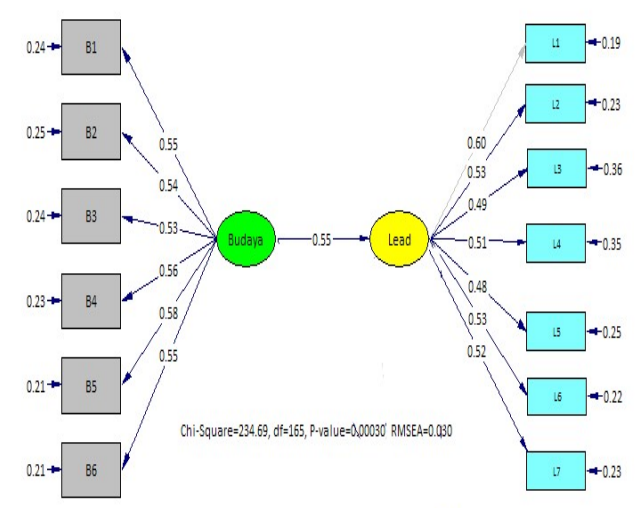

Figure 2. Path diagram of organizational culture on leadership

Based on the calculation results of the first hypothesis, it can be described that organizational culture affects leadership by 55\% through values, norms, beliefs, and artifacts that are implemented in process orientation, employee orientation, professionalism, open systems, loose supervision, and normative supervision. The primary dimension which builds an organizational culture in influencing leadership is the relatively loose supervision imposed in the organization. Thus, the loose organizational culture applied in banking organizations such as giving employees the freedom to complete tasks and only doing occasional tight supervision has a vital role in 
Jurnal Bisnis dan Manajemen, Volume 20, No. 1, March 2019, p. 71-88

influencing leadership. In its interaction, the organizational culture applied in banking organizations emphasizes the leadership application on the dimension of inspirational motivation. Thus, through the values which exist in the organizations considered as the shared values or organizational culture, leaders can inspire their employees to complete work better by performing better communication, using symbols to focus on the business and simply expressing the importance of goals.

\section{Effect of organizational culture on work motivation}

The results of statistical calculations using the Lisrel program show that organizational culture directly affects the work motivation of banking employees by $28 \%$. In addition to direct influence, this study also shows that there is an indirect influence of organizational culture on employee motivation through the leadership of $21.4 \%$. The test results show that the organizational culture which tends to apply loose supervision to the employees can influence employee's motivation at work.

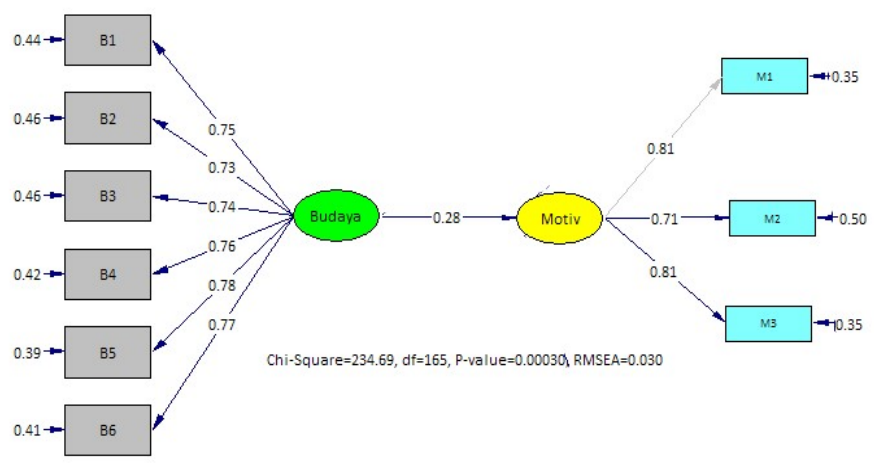

Figure 3. Path diagram of organizational culture on work motivation
The results of the second hypothesis test show that in banks in Southeast Sulawesi, organizational culture directly influences work motivation by $28 \%$. The essential elements of organizational culture which include shared values, beliefs, and behaviors that are expected by employees, can affect employee motivation through the process of socialization in the organization. Employees learn the behavior that is permissible, how activities in the organization are carried out, and norms are developed, accepted and jointly used by individuals in the organization.

Besides, fundamental values, assumptions, and beliefs are used as a model of behavior and activity and are reflected as structures, policies, practices, and management procedures and practices. These, of course, affect employee motivation in the company. Therefore, individuals working in organizations can feel the available values and then decide how they act in their working environment.

The result shows that there is an influence of organizational culture on work motivation. It is relevant to the opinion of Harris and Mossholder (1996), Markus \& Kitayama (1991), Straub (1999), and Kreitner \& Kinicki (2004). They explained that organizational culture stands as the center of various factors derived through human resource management and is believed to affect employee motivation through the suitability of individual characteristics and the organizational culture that is applied.

Based on the calculation results, it can be described that organizational culture applying a 
Jurnal Bisnis dan Manajemen, Volume 20, No. 1, March 2019, p. 71-88

loose supervision influences work motivation which is formed through social dimension and mental dimension. Loose supervision has an essential role in work motivation. In its interaction, the organizational culture of banking organization which is following the characteristics of employees, causes employees to be more motivated at work. This condition desired by most employees is in line with the opinion of Barbuto (2005) stating that this condition is part of selfconcept-external-motivation.

Work motivation that is influenced by organizational culture in Southeast Sulawesi banking organizations tends to be externally. It is based on the view that individuals are otherdirected and try to strengthen the traits, competencies, and values from an external perspective. Generally, the application of organizational culture that is mostly process oriented can influence employee motivation, especially in the social dimension involving the importance of interpersonal relationships between employees in the organization.

\section{Effect of organizational culture and leadership on work motivation}

The results of statistical calculations using the Lisrel program indicate that work motivation is significantly and positively influenced by organizational culture and leadership. Partially, the influence of organizational culture and leadership is respectively $(0.28 * 0.28)=7.84 \%$ and $(0.39 * 0.39)=15.21 \%$. The results of calculations show that organizational culture and leadership can influence work motivation by $36 \%$, while the rest of work motivation is influenced by other variables other than organizational culture and leadership variables.

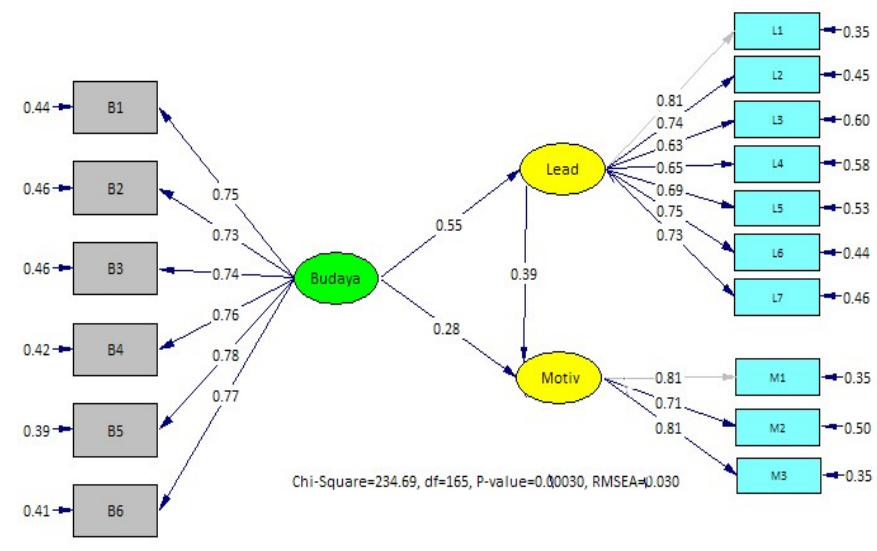

Figure 4. Path diagram of organizational culture and leadership on work motivation

These results indicate that the application of constructive organizational culture and the role of leader as the inspirational motivation can create conditions which can motivate employees to work. This process occurs through socialization which can create an organizational culture which is process oriented, employee orientated, professional, open system, loose in supervision, and normative. For this reason, the role of leaders is also needed to create a vision based on the current organizational culture and to improve the vision, values, and norms that are used as shared values agreed upon by the employees.

The results of the third hypothesis testing in this study show that there is a significant influence of organizational culture and leadership variables on employee work motivation. This influence is built through a process-oriented 
organizational culture and the application of inspirational leadership within the organization. This result is relevant to the opinion of Gallagher (2002) and Block (2003) stating that organizational culture can influence the application of leadership in organizations and encourage employees to work better since the leaders play important roles such as motivators, team builders and visionaries.

Table 2. Decomposition of the effect of the exogenous latent variable on the endogenous latent variable (work motivation)

\begin{tabular}{cccc}
\hline $\begin{array}{c}\text { Exogenous } \\
\text { latent } \\
\text { variable }\end{array}$ & $\begin{array}{c}\text { Dir } \\
\text { ect }\end{array}$ & $\begin{array}{c}\text { Effect } \\
\text { Indirect } \\
\text { Through }\end{array}$ & Total \\
\cline { 2 - 4 } Culture & 0.28 & 0.214 & 0.494 \\
Leadership & 0.39 & - & 0.39 \\
\hline
\end{tabular}

\section{Effect of Organizational Culture, Leadership, and Motivation on Employee Performance}

The fourth hypothesis testing was conducted to test the simultaneous influence of organizational culture, leadership, and work motivation on employee performance. Individually, leadership influences employee performance by $(0.33 * 0.33)$ $=10.89 \%$ and employee work motivation influences employee performance by $(0.21 * 0.21)$ $=4.41 \%$. This significant and positive influence shows that organizational culture, as the mutually agreed values, indirectly creates a situation where employees are on the same track. These values are dominated by the constructive organizational culture that influences leadership through its role as inspirational motivation. This role can create a vision that is further socialized to employees, supported by other transformational leadership the natures, namely integrity, innovation, impression management, individual consideration, intellectual stimulation, and trust.

Employee work motivation, dominated by social or interpersonal relationships in the organization, can simultaneously and significantly affect employee performance in a positive direction. Thus, the better the applications of organizational culture and transformational leadership are, along with the strong work motivation, the better the achievement of employee performance will be.

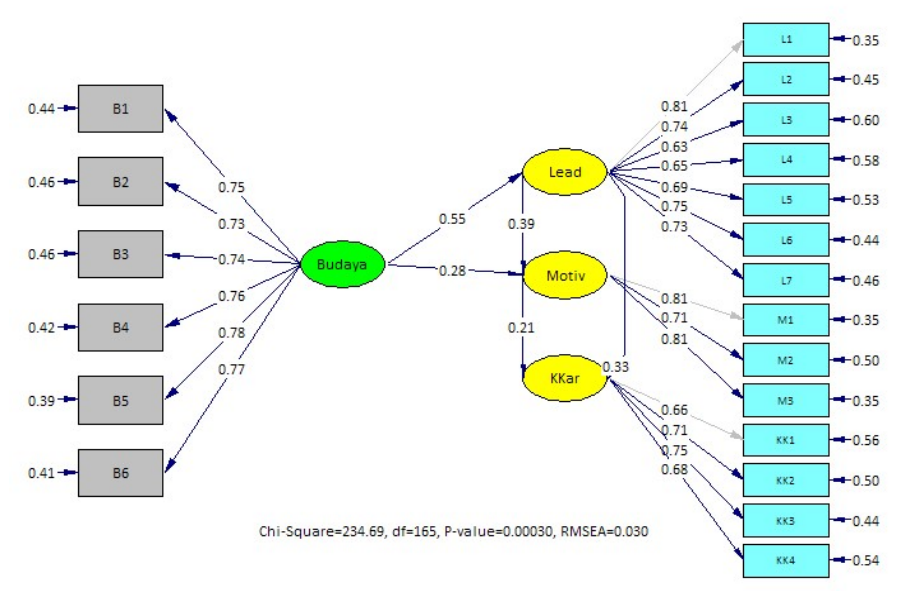

Figure 5. Path diagram of organizational culture, leadership, and work motivation on employee performance

Simultaneously, organizational culture, leadership and work motivation significantly influence employee performance by $23 \%$. The results of this study indicate that leadership and work motivation are essential factors in determining the success or failure of employee performance. This finding supports the statement of Shamir (1991) who explained the opinion of Bass Avolio about leadership, placing value and giving attention to the development of a vision and 
inspiration to the followers for achieving that vision. They focused their efforts on long-term vs. short-term goals and the need to change or improve the existing systems to accommodate vision.

They also emphasized the need to train employees to be more responsible for what they develop through elements such as idealized influence, inspirational motivation, intellectual stimulation, and individualized consideration. It can increase employee motivation and selfconfidence and increase other positive and innovative thoughts.

In addition to leadership, motivation associated with the work values both at the employee level and at the organizational level can encourage employees to work harder. Besides, performance cannot be separated from dynamic employee values and attitudes (Hofstede, 1991), thus affecting employee performance. This idea is reinforced by the opinions of Martins and Terblanche (2003) who explained that organizational culture plays a role in creating creativity and innovation focusing on the characteristics of the personality and intellectual abilities of employees. In general, the results of this study are in line with the opinion of Scott \& Walker (1995: 84) and Kopelman (1986) stating that employee performance in an organization is influenced by several aspects, namely; individual including motivation; task including goals dan targets; team including leadership, norms, values, suitability; and organizational aspects including structure, climate, development support, and culture.

The results of this study generally justify the hypothesis model stating that there are significant and positive effects of leadership, work motivation, and organizational culture on employee performance. Based on the calculation results, it is shown that leadership variable including inspirational motivation, integrity, innovation, impression management, individual consideration, intellectual stimulation, trust, and work motivation variable including social dimensions, mental dimensions, and physical dimensions which is influenced by organizational culture through process orientation, employee orientation, open system, professionalism, loose supervision, and pragmatic system, will have a significantly positive effect on employee performance. The results of statistical tests have proven that there are significant effects of leadership and work motivation variables on employee performance.

Besides, this study also found an indirect influence of organizational culture on employee performance. Statistical calculations using Lisrel program to calculate the amount of indirect influence of organizational culture on employee performance are presented in table 3. 
Jurnal Bisnis dan Manajemen, Volume 20, No. 1, March 2019, p. 71-88

Table 3. Decomposition of effect of exogenous latent variable on end ogen ous latent variable (employee performance)

\begin{tabular}{cccccc}
\hline $\begin{array}{c}\text { Exogenous latent } \\
\text { variable }\end{array}$ & Direct & $\begin{array}{c}\text { Effect } \\
\text { Through } \\
\text { leadership }\end{array}$ & $\begin{array}{c}\text { Through } \\
\text { motivation }\end{array}$ & $\begin{array}{c}\text { Through } \\
\text { leadership } \\
\text { and } \\
\text { motivation }\end{array}$ & Total \\
\hline Culture & - & 0.185 & 0.0588 & 0.045 & 0.285 \\
Leadership & 0.33 & - & 0.081 & - & 0.411 \\
Motivation & 0.21 & - & - & - & 0.21 \\
\hline
\end{tabular}

Table 3 shows that organizational culture influences employee performance indirectly through leadership, work motivation and leadership and work motivation. The calculation results show that organizational culture affects employee performance both directly and indirectly. Indirectly, organizational culture influences employee performance through leadership by $18.5 \%$. It can be interpreted that organizational culture influences the application of leadership in creating a vision and mission and in revising the shared norms, values and assumptions by not hindering employees in pursuing their aspirations, by providing rewards and by treating employees as family members. Through work motivation, organizational culture affects employee performance by $5.88 \%$. It shows that the organizational culture applied in banking organizations can motivate employees through employee interpersonal relationships and collaboration in completing various jobs. Whereas through leadership and work motivation, organizational culture affects employee performance by $4.85 \%$. This result shows that organizational culture provides a pattern of employee behavior to be on the same track and can influence the application of leadership in creating a vision and mission which is then socialized to employees to be achieved together.

Overall, constructive organizational culture can indirectly influence employee performance by $28.5 \%$ through the leadership variable with the 'new leadership' approach. Organizational culture is also able to motivate employees to work in achieving their goals. This result is relevant to the opinion of Petty et al. (1995), Franco \& Bourne (2003) and Nudurupati et al. (2003) stating that organizational culture is an important factor supporting the performance increasing implementation through a cultural approach. This culture approach supports work teams, owners and companies, focused on continuous achievement.

\section{CONCLUSIONS AND RECOMMENDATIONS}

Based on the results of the analysis, the following descriptive conclusions can be drawn. First, the organizational culture applied in the Southeast Sulawesi banking organizations is generally constructive, including to be process-oriented which prioritizes the completion of various tasks within the organization. It is a learning process for employees. Organizational culture is an employeeoriented approach by giving sufficient attention to the employees in a professional way. It can be seen from several aspects such as the placement of employees under their expertise and skills, the application of organizations as an open system by always helping new employees to assimilate the 
Jurnal Bisnis dan Manajemen, Volume 20, No. 1, March 2019, p. 71-88

prevailing organizational culture, and the encouragement to employees to participate in various activities in the surrounding community.

Second, the leadership applied in banking organizations in Southeast Sulawesi is a new leadership approach. In general, this model of leadership implementation leads to several aspects, namely inspirational motivation built through sincerity of leaders in listening to employee complaints, integrity built through the courage of leaders in taking a stand against various issues, innovation built through the way of viewing mistakes as a learning process and leadership ability in developing various innovations, impression management built through award giving to outstanding employees, individual consideration built through the ability to provide ideas for the development and progress of the company, intellectual stimulation built through the assertiveness of leaders, and trust which is built through integrity in upholding employee's interests.

Third, work motivation of banking employees in Southeast Sulawesi is generally built through social, physical and mental dimensions. Motivation is more influenced by social relations between employees in the workplace, comfort and security felt by employees, and sufficient income received by employees.

Fourth, the performance of banking employees influenced by organizational culture, leadership and work motivation variable is generally in the good category. It can be seen from the factors which become the evaluations of employee performance, namely financial perspective, external perspective, internal perspective and knowledge, and learning perspective. However, this achievement was not optimally achieved as expected.

In addition to the descriptive conclusions explained above, the verification conclusions can also be drawn as follows. First, organizational culture has a significant and positive influence on leadership, especially in creating a constructive culture that is flexible, innovative, and adaptive in facing various changes and uncertainties in the organization.

Second, organizational culture has a significant and positive influence on employee motivation. It implies that the application of organizational culture which is a manifestation of the values, norms and shared assumptions can affect employee motivation at work.

Third, the partial and simultaneous influence of organizational culture and leadership on work motivation is significant. In this case, constructive organizational culture including process orientation, employee orientation, parochial system, open system, loose supervision approach, and normative system, along with leadership based on transformational leadership highlighting inspirational motivation, can create conditions that can affect employees to work well.

Fourth, the partial and simultaneous influences of organizational culture, leadership, and work motivation on employee performance are significant. In this study, organizational culture influences employee performance indirectly 
Jurnal Bisnis dan Manajemen, Volume 20, No. 1, March 2019, p. 71-88

through leadership and work motivation. Integrated and constructive organizational culture provides a strong foundation for the application of leadership highlighting the behavior of inspirational motivation. Also, employee work motivation built by social dimensions and physical dimensions can positively influence employee performance.

To increase the influence of organizational culture on the application of leadership, employee motivation, and employee performance, Southeast Sulawesi banking organizations need to do the following. First, they should implement a processoriented organizational culture by empowering the authorities in the organization to provide understanding to employees in their work so that the job risks can be minimized. Second, they should implement an employee-oriented organizational culture by increasing employee participation in determining various decisions made for mutual interests. Third, they should implement a professional organizational culture to improve employee professionalism in order to broaden the horizons of the employee by involving employees in various training and education. Fourth, they should also implement an open organizational culture by improving employees' physical environment to increase their comfort at work. Fifth, they should implement an organizational culture that conducts loose supervision by increasing supervision of new employees in completing various tasks following work standardization, as well as providing flexibility for employees to complete various tasks by developing their potential and ideas.

To further enhance the leadership role in motivating employees and creating optimal employee performance, Southeast Sulawesi banking organizations should always try to listen to employees' complaints and try to provide the best solutions in order to help ease their burdens.

Further research is suggested to map the results of employee performance achievement to Total Quality Management, Competency Management, and Kolb Learning Cycle as a continuous process to improve employee performance in banking organizations more optimally. Regarding Total Performance Scorecard, the further research may examine the direct effect of the organizational culture, leadership, and work motivation as well as employee performance on organizational performance by increasing the number of analysis unit or sample size. Finally, further research may explore the computation of the Structural Equation Modeling (SEM) equation to handle a study that has two different units of analysis. It is because, in the concept of Total Performance Scorecard, the achievement of employee performance and organizational performance can fulfill reciprocal relationships.

\section{REFERENCES}

Barbuto, J.E. Jr. (2005). Motivation and Transactional, Charismatic, and Transformational Leadership: A Test of Antecedents. Journal of Leadership \& 
Jurnal Bisnis dan Manajemen, Volume 20, No. 1, March 2019, p. 71-88

Organizational Studies. Flint:Vol.11, Iss. 4; pg. 26, 15 pgs.

Bass, B.M. (1985). Leadership and Performance Beyond Expectations. The Free Press.

................ (1990). Bass and Stogdill's Handbook of Leadership, 3rd Edition., Free Press, New York, NY.

(1995). Transformational Leadership Redux. Leadership Quartely. Vol. 6. pp. 463-478.

Blanchard, K. and Wakin, E. (1991). Managing : Different Styles for Different People: Give Employees Feedback, not Criticism. Today's Office, Vol. 26 No. 3, August, pp. 20-3.

Block, L. (2003). The Leadership-Culture Connection : an Exploratory Investigation. Leadership \& Organization Development Journal. Volume 24. Number 6. pp. 318334.

Daft, R. L.. (1998). Organization Theory and Design. $6^{\text {th }}$ Edition. South Western College Publishing. USA.

Franco, M., \& Bourne, M. (2003). Factors that Play a Role In Managing Through Measures. Management Decisions. Vol. 41 No. 6. pp.281-209.

Gallagher, R. S. (2002). The Soul of an Organization : Increasing Productivity and Profits by Assesing, Identifying, and Improving Your Corporate Culture. Dearborn Trade Press.

Hays, W. L. (1976). Quantification in Psychology. Prentice Hall. New Delhi.

Harris, S. G. \& Mossholder, K. W. (1996). The Affective Implications of Perceived Congruence with Culture Dimensions during Organizational Transformation. Journal of Management, 22, 527 - 547.

Hofstede, Geert, Bond, Michael \& Richard Frankee. (1991). Cultural Roots of Economic Performance : A Research Note. Strategic Management Journal. Summer. Vol 12, 165173 ; ABI/INFORM global.

Hofstede, G. and Hofstede, G. J. (2005). Cultures and Organsizations - Software of the Mind. McGraw-Hill, NY

Kopelman E. R. (1986). Managing Productivity in Organization. McGrawHill. USA.
Kreitner, R dan Kinicki, A. (2004). Organizational Behaviour. McGraw Hill. Irwin.

Markus, H.R., \& Kitayama, S.. (1991). Culture and the Self: Implication for Cognition, Emotion, and Motivation. Psychological Review. 98. pp.224-253.

Martins, E.C., \& F Terblanche. (2003). Building Organisational Culture that Stimulates Creativity and Innovation. European Journal of Innovation Management. Bradford: 2003.Vol.6, Iss. 1; pg. 64, 11 pgs.

Nudurupati, S.S.. (2003). Management and Business Implications of IT- Supported Performance Measurement. Univercity of Strathclyde. UK.

Ogbonna, E. and Harris, C. (2000). Leadership Style, Organizational Culture, and Performance : Empirical Evidence from UK Companies. The International Journal of Human Resource Management. pp.766-788

Osteraker, Maria C. (1999). Measuring Motivation in a Dynamic Organization - A Contingency Approach. Journal of Strategic Change. Mar/Apr.pg. 103.

Petty, M.M., Beadles II, N.A., Lowery, C.M. (1995). Relationships between Organizational Culture and Organizational Performance. Vol. 76 No.2s. pp.483-92.

Pounder. S. J. (2001). New Leadership and University Organizational Effectiveness : Exploring the Relationship. Leadership and Organizational Development Journal. Vol 22. pp 281-291.

Rampersad, H., K. (2003). Total Performance Scorecard : Redefining Management to Achieve Performance with Integrity. Massachusetts : Butterworth-Heinemann Business Books. Elsevier Science.

Schein, H. E. (1992). Organizational, Culture, and Leadership. $2^{\text {nd }}$ Edition. Jossey-Bass Publisher. San Fransisco.

Scott \& Walker. (1995). Management. $2^{\text {nd }}$ Edition. McGraw-Hill.

Shamir, B. (1991). The Charismatic Relationship $\therefore$ Alternative Explanations and Predictions. The Leadership Quarterly, 2, 81-104.

Straub, H. (1999). Designing A Cross-Cultural Course. Vol 37. Number 3. 
Jurnal Bisnis dan Manajemen, Volume 20, No. 1, March 2019, p. 71-88

Yousef, A. D. (1998). Correlates of Perceived Leadership Style in a Culturally Mixed Environment. Leadership \& Organization Development Journal 19,5 275-284.

Yukl, G. (2001). Leadership in Organization. $5^{\text {th }}$ Edition. Upper Saddle River. NJ ; Prentice Hall. 